\title{
Rancang Bangun Sistem Pembangkit Listrik Tenaga Air Menggunakan Konsep Hydrocat
}

\author{
Syaiful Anwar ${ }^{*}$, Muhamad Taufiq Tamam², Itmi Hidayat Kurniawan ${ }^{3}$ \\ 1,2,3Program Studi Teknik Elektro, Fakultas Teknik dan Sains, Universitas Muhammadiyah Purwokerto \\ Jl. K.H. Ahmad Dahlan Dukuhlawuh Purwokerto \\ "Email: : aan.war0404@gmail.com.
}

\begin{abstract}
ABSTRAK
Seiring perkembangan jaman, saat ini energi listrik telah menjadi salah satu kebutuhan primer dalam kehidupan sehari-hari, baik untuk melakukan pekerjaan ataupun kegiatan yang lainnya. Pembangkit Listrik Tenaga Air atau PLTA dengan menggunakan konsep hydrocat merupakan sebuah konsep pembangkit listrik yang diciptakan untuk aliran jalur irigasi yang memiliki ukuran tidak terlalu besar dan tingkat kedalamannya yang rendah. Oleh karena itu dibuatlah rancang bangun sistem pembangkit listrik menggunakan konsep hydrocat. Pada penelitian ini menggunakan generator DC sebagai sumber tenaga listrik dan menggunakan jenis turbin undershot. Penelitian ini dilakukan di Desa Karang Cegak Kecamatan Kutasari Kabupaten Purbalingga. Beban pada penelitian ini menggunakan lampu LED SMD 1,2 Watt, 2,4 Watt 3,6 Watt, dan 4,8 Watt. Alat ini mampu menghasilkan putaran pulley turbin air sebesar 69,2 rpm, 60,8 rpm, 59,0 rpm, 58,7 rpm, 57,1 rpm, dan 56,7 rpm. Putaran pulley generator DC sebesar 595,9 rpm, 586,1 rpm, 520,1 rpm, 506,2 rpm, dan 496,0 rpm. Besar tegangan yang dihasilkan 31,86 Volt, 9,20 Volt, 8,61 Volt, 8,38 Volt, dan 8,25 Volt. Besar arus yang dihasilkan sebesar 0,02 Ampere, dan besar daya yang dihasilkan sebesar 0,1836 Watt, 0,1718 Watt, 0,1671 Watt, dan 0,165 Watt.
\end{abstract}

Kata kunci: PLTA, hydrocat, generator DC, turbin undershotABSTRACT

\begin{abstract}
Along with the development of the times, nowadays electrical energy has become one of the primary needs in everyday life, both for doing work or other activities. Hydroelectric Power or Hydroelectric Power using the hydrocat concept is a power generation concept created for irrigation channel flow that is not too large and has a low depth level. Therefore, a power plant system design using the hydrocat concept was made. In this study using a DC generator as a source of electricity and using a type of undershot turbine. This research was conducted in Karang Cegak Village, Kutasari District, Purbalingga Regency. The load in this study uses 1.2 Watt SMD LED lamps, 2.4 Watt 3.6 Watt, and 4.8 Watt. This tool is capable of producing water turbine pulley rotation of $69.2 \mathrm{rpm}, 60.8$ rpm, $59.0 \mathrm{rpm}, 58.7 \mathrm{rpm}, 57.1 \mathrm{rpm}$, and $56.7 \mathrm{rpm}$. DC generator pulley rotation of $595.9 \mathrm{rpm}, 586.1$ rpm, $520.1 \mathrm{rpm}, 506.2 \mathrm{rpm}$, and $496.0 \mathrm{rpm}$. The resulting voltages are 31.86 Volts, 9.20 Volts, 8.61 Volts, 8.38 Volts, and 8.25 Volts. The amount of current generated is 0.02 Ampere, and the amount of power generated is 0.1836 Watt, 0.1718 Watt, 0.1671 Watt, and 0.165 Watt.
\end{abstract}

Key words: hydropower, hydrocat, DC generator, undershot turbine

\section{PENDAHULUAN}

Energi listrik yang umum digunakan saat ini merupakan energi listrik yang dihasilkan oleh PT. PLN yang menggunakan bahan bakar tidak terbarukan atau bahan bakar fosil. Air adalah salah satu sumber energi yang mudah didapatkan dan relatif ekonomis. Pemanfaatan aliran lepas pada jalur irigasi yang mengalir secara kontinu (terus-menerus) dapat digunakan sebagai penggerak turbin yang dapat menghasilkan energi listrik. Energi listrik yang dihasilkan dari pemanfaatan aliran air tersebut termasuk dalam energi yang ramah lingkungan atau dapat disebut dengan Pembangkit Listrik Tenaga Air (PLTA).
Kondisi air yang bisa dimanfaatkan sebagai sumber daya penghasil listrik ialah kondisi air yang memiliki kapasitas aliran dan ketinggian tertentu dari instalasi. Semakin besar kapasitas aliran maupun ketinggiannya dari instalasi maka semakin besar energi yang bisa dimanfaatkan untuk menghasilkan energi listrik. Istilah kapasitas mengacu kepada jumlah volume aliran air persatuan waktu flow capacity, sedangkan beda ketinggian daerah aliran sampai ke instalasi dikenal dengan istilah head [1].

Tenaga air hydropower adalah energi yang diperoleh dari air yang mengalir. Pada air tersimpan energi potensial dan energi kinetik terdapat pada air mengalir. Pemanfaatan roda air sebagai komponen utama pembangkit listrik skala kecil mulai 
RESISTOR (Elektronika Kendali Telekomunikasi Tenaga Listrik Komputer) Vol. 4 No. 1 e-ISSN : 2621-9700, p-ISSN : 2654-2684

dikembangkan khususnya pada daerah-daerah aliran air yang rendah dan head yang cenderung rendah [2].

Pico hydro power secara teknologi memiliki efisiensi yang tinggi sehingga dapat meningkatkan pengetahuan masyarakat tentang menajemen energi. Selain memiliki efisiensi tinggi, pico hydro power juga dinilai aman [3].

Pembangkit listrik mikrohidro dan pikohidro cocok untuk aliran air dengan debit yang rendah atau kecil. Rugi-rugi daya pada penggunaan turbin overshot diidentifikasi dan dianalisis dengan proses optimasi sehingga rugi-rugi tersebut bisa dieliminasi dan nilai efisiensinya bisa meningkat [4].

Potensi mikrohidro di Indonesia sekitar 7.500 MW, namun yang dimanfaatkan baru sekitar $10 \%$. Rasio elektrifikasi juga masih rendah, untuk pulau Jawa saja belum mencapai 90\%. Saluran irigasi pertanian yang tersedia sangat mungkin untuk dimanfaatkan sebagai pembangkit listrik karena memiliki debit yang stabil [5].

Pembangkit listrik alternatif dengan sistem penggerak awal motor DC dengan transfer gerak mekanik menggunakan pulley dan fan belt sebagai penggerak alternator DC. Tegangan yang dihasilkan dimanfaatkan untuk menghidupkan inverter sehingga bisa untuk menghidupka peralatan listrik [6].

Hasil studi potensi pembangkit listrik piko hidro di sekitar sungai Bangun Mulyo Sleman merekomendasikan untuk dibangun Pembangkit Listrik Tenaga Piko Hidro karena dapat menghasilkan daya listrik sebesar 3,67 KW [7].

\section{METODOLOGI}

Prinsip kerja dari kincir air tipe undershot adalah ketika aliran sungai atau aliran air menumbuk salah satu dari blade, maka blade akan bergerak mengikuti arah aliran air dan secara bergantian masing-masing blade akan tertumbuk oleh aliran air sehingga kincir air akan memutarkan poros. Poros kincir dihubungkan dengan generator, sehingga generator akan berputar dan menghasilkan listrik. Bentuk turbin undershoot yang digunakan ditunjukkan pada Gambar 1. Bagian turbin yang terkena air hanya pada ujung-ujung blade-nya saja karena posisi turbin adalah terapung.

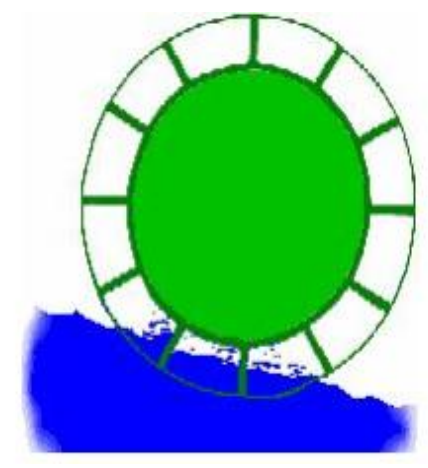

Gambar 1. Turbin undershot

Diagram blok sistem secara keseluruhan ditunjukkan pada Gambar 2.

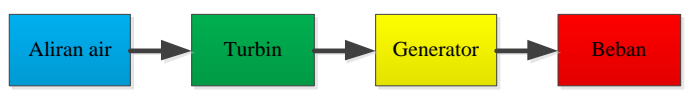

Gambar 2. Diagram blok sistem

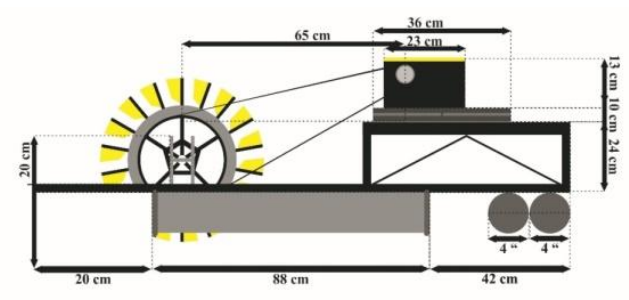

Gambar 3. Rancangan sistem

\section{HASIL DAN PEMBAHASAN}

Sistem merupakan bentuk Pembangkit Listrik Tenaga Air yang memanfaatkan air di saluran irigasi pertanian dengan menggunakan konsep hydro cat. Turbin yang digunakan adalah jenis undershot. Aliran air irigasi menggerakkan turbin yang sudah dikopel dengan genarator DC. Debit air yang relatif stabil sehingga listrik yang dihasilkan juga relatif stabil. Listrik DC yang dihasilkan bisa untuk menyalakan beban yang berupa lampu LED.

Tabel 1. Hasil pengujian tegangan keluaran

\begin{tabular}{|c|c|c|c|c|}
\hline \multirow[b]{2}{*}{$\begin{array}{c}\text { Durasi } \\
\text { (menit } \\
\text { ) }\end{array}$} & \multicolumn{4}{|c|}{ Tegangan (V) } \\
\hline & $\begin{array}{c}\text { Beba } \\
n \\
12 \mathrm{~W}\end{array}$ & $\begin{array}{c}\text { Beba } \\
n \\
2,4 \mathrm{~W}\end{array}$ & $\begin{array}{c}\text { Beba } \\
n \\
3,6 \mathrm{~W}\end{array}$ & $\begin{array}{c}\text { Beban } \\
4,8 \mathrm{~W}\end{array}$ \\
\hline $0-5$ & 9,20 & 8,62 & 8,38 & 8,2 \\
\hline $5-10$ & 9,21 & 8,60 & 8,3 & 8,26 \\
\hline $10-15$ & 9,19 & 8,61 & 8,37 & 8,26 \\
\hline $15-20$ & 9,20 & 8,62 & 8,39 & 8,25 \\
\hline $20-25$ & 9,22 & 8,62 & 8,37 & 8,26 \\
\hline $25-30$ & 9,19 & 8,59 & 8,41 & 8,26 \\
\hline
\end{tabular}


RESISTOR (Elektronika Kendali Telekomunikasi Tenaga Listrik Komputer) Vol. 4 No. 1 e-ISSN : 2621-9700, p-ISSN : 2654-2684

Tabel 1 menunjukkan hasil pengukuran tegangan keluaran dengan beban yang bervariasi. Untuk nilai beban terpasang yang sama tegangan keluaran yang dihasilkan relatif stabil. Semakin besar daya beban yang terpasang maka tegangan keluaran yang dihasilkan semakin kecil.

Tabel 2. Hasil pengujian arus keluaran

\begin{tabular}{ccccc}
\hline \multirow{2}{*}{$\begin{array}{c}\text { Durasi } \\
\text { (menit }\end{array}$} & $\begin{array}{c}\text { Beba } \\
\mathrm{n}\end{array}$ & $\begin{array}{c}\text { Beba } \\
\mathrm{n}\end{array}$ & $\begin{array}{c}\text { Beba } \\
\mathrm{n}\end{array}$ & $\begin{array}{c}\text { Beban } \\
\text { ) }\end{array}$ \\
$12 \mathrm{~W}$ & $2,4 \mathrm{~W}$ & $3,6 \mathrm{~W}$ & \\
\hline $0-5$ & 0,02 & 0,02 & 0,02 & 0,02 \\
$5-10$ & 0,02 & 0,02 & 0,02 & 0,02 \\
$10-15$ & 0,02 & 0,02 & 0,02 & 0,02 \\
$15-20$ & 0,02 & 0,02 & 0,02 & 0,02 \\
$20-25$ & 0,02 & 0,02 & 0,02 & 0,02 \\
$25-30$ & 0,02 & 0,02 & 0,02 & 0,02 \\
\hline
\end{tabular}

Tabel 2 menunjukkan hasil pengukuran arus keluaran dengan beban yang bervariasi. Arus keluaran yang dihasilkan konstan sebesar 0,02 Ampere.

Tabel 3. Hasil pengujian daya keluaran

\begin{tabular}{ccccc}
\hline \multirow{2}{*}{$\begin{array}{c}\text { Durasi } \\
\text { (menit }\end{array}$} & $\begin{array}{c}\text { Beba } \\
\mathrm{n}\end{array}$ & $\begin{array}{c}\text { Beba } \\
\mathrm{n}\end{array}$ & $\begin{array}{c}\text { Beba } \\
\mathrm{n}\end{array}$ & $\begin{array}{c}\text { Beban } \\
\text { ) }\end{array}$ \\
$12 \mathrm{~W}$ & $2,4 \mathrm{~W}$ & $3,6 \mathrm{~W}$ & \\
\hline $0-5$ & 0,184 & 0,172 & 0,167 & 0,165 \\
$5-10$ & 0,184 & 0,172 & 0,167 & 0,165 \\
$10-15$ & 0,183 & 0,172 & 0,167 & 0,165 \\
$15-20$ & 0,184 & 0,172 & 0,167 & 0,165 \\
$20-25$ & 0,184 & 0,172 & 0,167 & 0,165 \\
$25-30$ & 0,183 & 0,171 & 0,168 & 0,165 \\
\hline
\end{tabular}

Tabel 3 menunjukkan hasil pengukuran daya keluaran dengan beban yang bervariasi. Untuk nilai beban terpasang yang sama daya keluaran yang dihasilkan relatif stabil. Semakin besar daya beban yang terpasang maka daya keluaran yang dihasilkan semakin kecil.

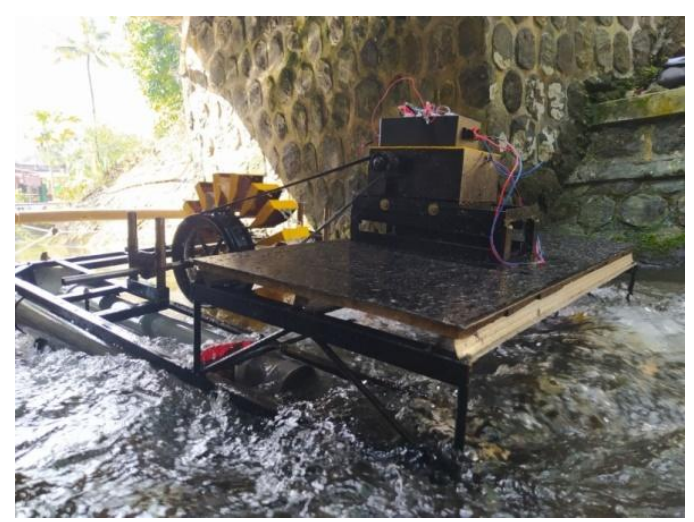

Gambar 4. Realisasi sistem

Gambar 4 menunjukkan sistem yang sudah jadi dan terpasang (terapung) pada aliran irigasi pertanian.

\section{KESIMPULAN}

Sistem yang dibuat pada penelitian sudah dapat bekerja sesuai dengan perencanaan, yaitu dapat menghasilkan tegangan listrik yang bersumber pada aliran irigasi yang digunakan untuk menggerakkan turbin yang sudah dikopel dengan generator DC. Hasil pengujian menunjukkan bahwa arus keluaran yang dihasilkan nilainya konstan sedangkan tegangan dan daya keluaran yang dihasilkan bervariasi tergantung pada besarnya daya beban yang terpasang.

\section{DAFTAR PUSTAKA}

[1] J. Y. Morong, "Rancang Bangun Kincir Air Irigasi Sebagai Pembangkit Listrik Di Desa Talawaan," Politeknik Negeri Manado, 2016.

[2] K. Jamlay, L. Sule, and D. Hasan, "Analisis perilaku aliran terhadap kinerja roda air arus bawah untuk pembangkit listrik skala pikohidro," Din. Tek. Mesin J. Keilmuan Dan Terap. Tek. Mesin, vol. 6, no. 1, 2016.

[3] W.-R. Engelke, W. Rakwichian, and N. Ketjoy, "An Assessment of Pico Hydro as an Option for Off-grid Electrification in Lao PDR: case study of Thapene village," J. Renew. Energy Smart Grid Technol., vol. 1, no. 2, pp. 55-62, 2006.

[4] E. Quaranta and R. Revelli, "Output power and power losses estimation for an overshot water wheel," Renew. Energy, vol. 83, pp. 979-987, 2015.

[5] I. Febijanto, "Pemanfaatan Potensi Tenaga Air di Saluran Irigasi Banjarcahyana, Kabupaten Banjarnegara, Propinsi Jawa Tengah sebagai Usaha Pengurangan Emisi Gas Rumah Kaca," J. Teknol. Lingkung., vol. 9, no. 3, 2011. 
RESISTOR (Elektronika Kendali Telekomunikasi Tenaga Listrik Komputer) Vol. 4 No. 1 e-ISSN : 2621-9700, p-ISSN : 2654-2684

[6] M. N. H. NAJAUTA, "RANCANG BANGUN PEMBANGKIT LISTRIK ALTERNATIF DENGAN BANTUAN PULLY DAN BELT MOTOR DC SEBAGAI PENGGERAK ALTERNATOR," Universitas Muhammadiyah Palembang, 2019.

[7] S. S. Asmara, "Studi Potensi Pembangkit Listrik Tenaga Piko Hidro Di Aliran Sungai Sekitar Bangunmulyo, Girikerto, Turi, Sleman.," Universitas Negeri Yogyakarta, 2016. 